\title{
Study on Emotional Intelligence Levels of Physical Education Teachers in Terms of Various Variables
}

\author{
Serkan T. AKA ${ }^{1} \&$ Adem SARIER $^{1}$ \\ ${ }^{1}$ Department of Physical Education, Ağrı İbrahim Çeçen University, Turkey \\ Correspondence: Serkan T. AKA, Department of Physical Education, Ağrı İbrahim Çeçen University, Turkey.
}

Received: September 6, 2019

Accepted: October 7, 2019 Online Published: February 21, 2020

doi:10.5539/ies.v13n3p111

URL: https://doi.org/10.5539/ies.v13n3p111

\begin{abstract}
For teaching profession, one of the important types of intelligence is emotional intelligence. Emotional intelligence levels of especially physical education teachers are expected to be high. The aim of this study is to examine emotional intelligence levels of physical education and sports teachers based on various variables. In this research, single screening model which is one of the General Survey models has been adopted. Population of the study consists of 320 Physical Education Teachers working in Ağrı in 2018-2019 academic years and its sample group consists of a total of 106 physical education teachers, of which 23 are female and 83 are male and who were selected from this population by random sampling method. "Personal Information Form" developed by researchers has been used in order to determine demographic characteristics of Physical Education Teachers, "Schutte Emotional Intelligence Scale" developed by Schutte et al. (1998) has been used in order to measure their emotional intelligence levels. According to findings, it has been seen that emotional intelligence levels of physical education teachers differentiate significantly in favor of physical education and sports teachers do not have administrative function in sub-dimension of utilizations of emotions according to administrative function variable. It has been determined that there is no significant difference between them according to gender, age and professional experience, education grade which is worked in, educational level, marital status, status of doing sports and smoking variables. Consequently, it is seen that emotional intelligence levels of physical education teachers are above medium level and there is no difference between them in terms of other variables except variable of having administrative function.
\end{abstract}

Keywords: intelligence, emotional intelligence, education, physical education, physical education teacher

\section{Introduction}

Intelligence is defined as "all thinking, reasoning, objective reality perceiving, judging and concluding abilities of a human" (http://tdk.gov.tr/2018). Intelligence is ability of mind to learn, to benefit from what is learned, to adapt to new situations and to find new solutions. It includes many functions of the mind such as perception, memory, thinking, learning (Yörükoğlu, 2004). Spearman' defined intelligence as follows. "There is a general intelligence that plays a role in all mental activities and this is called "g" factor (general factor). Mental capacity which is needed apart from general mental ability to demonstrate specific mental activity is called "s" factor (special factor). Measuring intelligence is measuring" (Selçuk, Kayıl1, \& Okut, 2004). According to Gardner, in order for something to be intelligent, there must be symbols, it must give importance to culture, help to create something and be capable of solving a problem that it has never encountered (As cited in Başaran, 2004). Gardner sees intelligence as the ability to find different solutions while solving problems and capacity to add products to the culture in which he/she lives. And he assumes that intelligence can't be explained in one-dimensional way, there are more than one intelligence and both cultural and biological factors are effective in shaping intelligence areas (Belenli, 2014).

Emotional intelligence which is one of the types of intelligence is a phenomenon that can undergo a change and can be developed, because it is associated with sociological and psychological state of an individual. The fact that an individual with high IQ values does not have good relations with people in social or business lives reveals that his emotional intelligence has not developed sufficiently. Therefore, an individual's high intelligence level is not proportionate to his/her emotional intelligence. Emotional intelligence is a concept that emerges and is shaped within a process (Tuğrul, 1999). According to Salovey and Mayer (1990), emotional intelligence is a dimension of social intelligence which includes ability to monitor his/her own and others' emotions, to distinguish between these 
emotions and to use information obtained for guiding thoughts and behaviors. Goleman (2014) describes emotional intelligence as the ability to recognize our and others' emotions, to get in the act, to manage emotions in us and our relationships, to regulate the mood by reflecting sensory information and energy of emotions to everyday life and work effectively, giving them appropriate reactions and to cherish the hope (Goleman, 2014). Emotional intelligence is a type of ability that expresses the effectiveness and rapid perception of individual emotions, individual's energy, knowledge, human relationships and development of movement ability with his/her perception related to this perception when his/her factors are evaluated collectively (Cooper \& Sawaf, 1997). While emotional intelligence is being explained, it is divided into two as "ability model" and "mixed model". Pioneer of ability model is emotional intelligence model of Mayer and Salovey and the pioneer of mixed model is Cooper and Sawaf Model, BarOn Model and the Goleman model. In mixed model, emotional intelligence concept was not discussed in one direction, it was also explained within the framework of social relationships and skills (Çakar \& Arbak, 2004; Doğan \& Şahin, 2007).

"Education" is one of the main concepts that can't be considered independently of the intelligence concept. In a broad sense, education means effects of all objects, institutions and individuals apart from themselves on individuals in terms of cognitive/mental, affective/emotional and social aspects in the environment where they are present. In the strict sense, education is a purposeful, intentional effect created on individual. This effect can be positive or negative and aims to change individual in desired direction at affective, cognitive, psychomotor levels (Şişman, 1999).

Education is the most important factor for a country to reach contemporary civilization level, advanced level of science and technique and as a result, welfare level. Today, aim of countries is to train skilled manpower through education (Demirci, 2011). In the most general definition, education is the process of train people according to specific aims. Personality of the person passing through this process becomes different. This differentiation occurs through knowledge, skills, attitudes and values gained during education process. For gaining desired knowledge, skills and attitudes and ensuring their sustainability, quality education offered in schools is very important. Physical education lessons which directly affect health of children in schools are the only lessons during which they can perform suggestion of World Health Organization (WHO) about minimum 60 minutes of daily physical activity.

Physical education is a set of movements that involve all educational physical activities such as games, gymnastics and sports that are performed as a team or individually, whose limits and objectives are determined with plans and programs, and that require preliminary preparation (Özmen, 1999; Çoban \& Ünveren, 2007). Main purpose of physical education and sports lesson which is an important part of general education is to help each student to reach the highest level of movement capacity by providing education through physical activities, i.e. movements. Physical education and sports lesson is an integral part of general education which has common purposes (Yavaş \& İlhan, 1997).

In education and training activities carried out in formal education institutions, physical education lesson is one of the lessons given in different fields for development of individuals as a whole. Physical education is one of the main lessons that contribute to emotional and social development as well as physical development and that play an important role in helping individuals to find their personality and to go in the right direction (Küçük, 2012; Yetim, 2005). People, who provide education related to physical education, are physical education teachers (UMBS, 2012). Physical education and sports teaching is defined as a specialization profession that is obliged to carry out physical education and sports lessons of preschool, primary and secondary education institutions and to carry out teaching, training, management and guiding duties of activities which are performed in the school and out of the school (Tunç, 1999).

Personal characteristics of physical education teachers are an important issue to consider. Personality revealed by teacher and relationship with students constitute an important connection between subject and student. Physical, psychological and mental characteristics of physical education teacher are important (Nebioğlu, 2004). When personal qualifications that a good physical education teacher should have, have been examined, it has been stated by students that physical education teachers should be nice, protective, helpful, willing, encouraging, perceiving, warm, lively, positive, patient, cheerful, understanding, emotional, honest, kind, sincere, careful, open-minded (Laminack \& Long, 1985).

Accordingly, emotional intelligence levels of physical education teachers are expected to be at acceptable level. Aim of this study is to examine emotional intelligence levels of physical education and sports teachers based on various variables. 


\section{Method}

In this research, single screening model which is one of the General Survey models has been adopted. Survey models are approaches aiming at defining the situation in the past or present as it is. An event, individual or object that is the subject of the research, is tried to be defined as it is in its conditions (Eroğlu, 2006).

Population of the study consists of 320 Physical Education Teachers working in Ağr1 in 2018-2019 academic years. Sample group of the study consists of a total of 106 physical education teachers, of whom 23 are female and 83 are male, and who works in different schools and can be reached in the population.

In the research, "Personal Information Form" developed by researchers has been used in order to determine demographic characteristics of Physical Education Teachers, "Schutte Emotional Intelligence Scale" developed by Schutte et al. (1998) has been used in order to measure their emotional intelligence levels.

Schutte Emotional Intelligence Scale (Schutte et al., 1998) originally consists of 33 items and single factor structure. Schutte Emotional Intelligence Scale was later revised by Austin, Saklofese, Huang, and McKenney (2004). As a result of such revision, item number of the scale was increased to 41 from 33 . In addition, some items in the first version of the scale were reversed and new items were added to scale. Austin et al. (2004) also suggested that factor structure of the Schutte Emotional Intelligence Scale didn't consist of single factor unlike the first version, it consisted of 3 factors. Austin et al. (2004) named new factors of the scale as "optimism/mood regulation, utilization of emotions and perceiving emotions". Schutte Emotional Intelligence Scale consists of 415 point Likert type items, of which 20 are positive and 21 are negative. Scale consists of Optimism/Mood Regulation, Utilisation of Emotions and Appraisal and Expression of Emotions factors and measures these three factors and general emotional intelligence as a whole (Göçet, 2006).

In the research, frequency analysis has been used in order to determine demographic characteristics of physical education teachers and descriptive statistics has been used in order to determine their general averages. Kolmogorov Smirnov test and Skewness-Kurtosis values have been examined in order to determine whether data distributed normally or not. According to this, t-test has been done in groups independent of parametric tests to determine whether there is a difference between emotional intelligence levels and some variables and according to other variables, one way analysis of variance (Anova) has been done. Results have been evaluated at 0.05 and 0.01 significance level.

\section{Findings}

Table 1. Normality distribution test results

\begin{tabular}{cccc}
\hline & Optimism Mood Regulation & $\begin{array}{c}\text { Utilizations of } \\
\text { Emotions }\end{array}$ & Appraisal of Emotions \\
\hline $\mathrm{N}$ & 106 & 106 & 106 \\
Mean & 48.5283 & 20.5849 & 38.0755 \\
Median & 49.0000 & 20.0000 & 39.0000 \\
Mode & 52.00 & 20.00 & 40.00 \\
Std. Deviation & 5.39878 & 4.05878 & 7.03555 \\
Skewness & -.474 & -.221 & -.681 \\
Std. Error of Skewness & .235 & .235 & .235 \\
Kurtosis & 1.493 & -.038 & .129 \\
Std. Error of Kurtosis & .465 & .465 & .465 \\
Minimum & 27.00 & 9.00 & 19.00 \\
Maximum & 60.00 & 30.00 & 50.00 \\
\hline
\end{tabular}

When normality distribution test results have been examined, it has been determined that among Emotional Intelligence Scale Sub-dimensions, Optimism Mood Regulation's Skewness value is -..474 and its Kurtosis value is 1.493, Utilizations of Emotions' Skewness value is -.221 and its Kurtosis value is -.038, Appraisal of Emotions' Skewness value is -.681 and its Kurtosis value is .129. It has been determined that Emotional Intelligence Scale Sub-dimensions' Skewness and Kurtosis values are between +1.96 and -1.96 and these statistical analysis results show that data distribute normally and parametric tests should be applied. 
Table 2. Frequency distribution of demographic characteristics of teachers participating in the research

\begin{tabular}{|c|c|c|c|}
\hline \multicolumn{2}{|l|}{ Variables } & $\mathrm{N}$ & $\%$ \\
\hline \multirow{3}{*}{ Gender } & Female & 23 & 21,7 \\
\hline & Male & 83 & 78.3 \\
\hline & Total & 106 & 100.0 \\
\hline \multirow{3}{*}{ Age } & Between 20-25 & 24 & 22.6 \\
\hline & Between 26-30 & 50 & 47.2 \\
\hline & 31 and older & 32 & 30.2 \\
\hline \multirow{2}{*}{ Marital Status } & Married & 44 & 41.5 \\
\hline & Single & 62 & 58.5 \\
\hline \multirow{2}{*}{ Educational Level } & Bachelor's degree & 96 & 90.6 \\
\hline & Master's Degree & 10 & 9.4 \\
\hline \multirow{2}{*}{ Education grade which is worked in } & Primary School & 43 & 40,6 \\
\hline & Secondary School & 63 & 59.4 \\
\hline \multirow{3}{*}{ Duty term in the profession } & $1-5$ years & 81 & 76.4 \\
\hline & $6-10$ years & 14 & 13.2 \\
\hline & 11 years and more & 11 & 10.4 \\
\hline Do you have Administrative & Yes & 9 & 8.5 \\
\hline Function? & No & 97 & 91.5 \\
\hline \multirow{2}{*}{ Do you engage in sports? } & Yes & 93 & 87.7 \\
\hline & No & 13 & 12.3 \\
\hline \multirow{2}{*}{ Do you smoke? } & Yes & 37 & 34.9 \\
\hline & No & 69 & 65.1 \\
\hline
\end{tabular}

Table 3. Results of independent group $t$ test conducted to determine whether scores of sub-dimensions of emotional intelligence scale differentiate according to gender variable of teachers or not

\begin{tabular}{|c|c|c|c|c|c|c|}
\hline $\begin{array}{c}\text { Emotional Intelligence Scale } \\
\text { Sub-Dimensions }\end{array}$ & Gender & $\mathrm{N}$ & $\mathrm{X}$ & Ss & $\mathrm{t}$ & $\mathrm{P}$ \\
\hline \multirow{2}{*}{ Optimism Mood Regulation } & Female & 23 & 49.6522 & 4.90462 & \multirow{2}{*}{1.130} & \multirow{2}{*}{.261} \\
\hline & Male & 83 & 48.2169 & 5.51505 & & \\
\hline \multirow{2}{*}{ Utilizations of Emotions } & Female & 23 & 20.4783 & 3.85969 & \multirow{2}{*}{-.142} & \multirow{2}{*}{.888} \\
\hline & Male & 83 & 20.6145 & 4.13442 & & \\
\hline \multirow{2}{*}{ Appraisal of Emotions } & Female & 23 & 38.0435 & 6.92478 & \multirow{2}{*}{-.025} & \multirow{2}{*}{.980} \\
\hline & Male & 83 & 38.0843 & 7.10754 & & \\
\hline
\end{tabular}

After $t$ test conducted to compare levels of sub-dimensions of emotional intelligence scale of male and female teachers, it has been found that there is no significant difference at $\mathrm{p}<.050$ significance level. 
Table 4. Results of one way analysis of variance (Anova) conducted to determine whether scores of sub-dimensions of emotional intelligence scale differentiate according to age variable of teachers or not

\begin{tabular}{|c|c|c|c|c|c|c|}
\hline $\begin{array}{l}\text { Emotional Intelligence Scale } \\
\text { Sub-Dimensions }\end{array}$ & Age & $\mathrm{N}$ & $\mathrm{X}$ & Ss & $\mathrm{F}$ & $\mathrm{P}$ \\
\hline \multirow{4}{*}{ Optimism Mood Regulation } & Between 20-25 & 24 & 49.5417 & 4.84525 & \multirow{4}{*}{.578} & \multirow{4}{*}{.563} \\
\hline & Between 26-30 & 50 & 48.3600 & 5.39372 & & \\
\hline & 31 and older & 32 & 48.0313 & 5.85020 & & \\
\hline & Total & 106 & 48.5283 & 5.39878 & & \\
\hline \multirow{4}{*}{ Utilizations of Emotions } & Between 20-25 & 24 & 20.5417 & 4.11761 & \multirow{4}{*}{.353} & \multirow{4}{*}{.703} \\
\hline & Between 26-30 & 50 & 20.9000 & 3.87167 & & \\
\hline & 31 and older & 32 & 20.1250 & 4.37552 & & \\
\hline & Total & 106 & 20.5849 & 4.05878 & & \\
\hline \multirow{4}{*}{ Appraisal of Emotions } & Between 20-25 & 24 & 38.7500 & 6.79674 & \multirow{4}{*}{.741} & \multirow{4}{*}{.479} \\
\hline & Between 26-30 & 50 & 38.5600 & 6.66444 & & \\
\hline & 31 and older & 32 & 36.8125 & 7.79759 & & \\
\hline & Total & 106 & 38.0755 & 7.03555 & & \\
\hline
\end{tabular}

After one way analysis of variance (ANOVA) test conducted to compare levels of sub-dimensions of emotional intelligence scale of teachers in different ages, it has been found that there is no significant difference at $p<.050$ significance level.

Table 5. Results of independent group t test conducted to determine whether scores of sub-dimensions of emotional intelligence scale differentiate according to variable of education grade in which teachers work or not

\begin{tabular}{|c|c|c|c|c|c|c|}
\hline $\begin{array}{c}\text { Emotional Intelligence Scale } \\
\text { Sub-Dimensions }\end{array}$ & Education Grade & $\mathrm{N}$ & $\mathrm{X}$ & Ss & $\mathrm{T}$ & $\mathrm{P}$ \\
\hline \multirow{2}{*}{ Optimism Mood Regulation } & Primary School & 43 & 48.9070 & 4.96566 & \multirow{2}{*}{.595} & \multirow{2}{*}{.353} \\
\hline & Secondary School & 63 & 48.2698 & 5.70005 & & \\
\hline \multirow{2}{*}{ Utilizations of Emotions } & Primary School & 43 & 20.6977 & 4.59054 & \multirow{2}{*}{.235} & \multirow{2}{*}{.814} \\
\hline & Secondary School & 63 & 20.5079 & 3.68901 & & \\
\hline \multirow{2}{*}{ Appraisal of Emotions } & Primary School & 43 & 37.7907 & 6.54493 & \multirow{2}{*}{-.343} & \multirow{2}{*}{.732} \\
\hline & Secondary School & 63 & 38.2698 & 7.39705 & & \\
\hline
\end{tabular}

After $\mathrm{t}$ test conducted to compare levels of sub-dimensions of emotional intelligence scale of teachers working in primary and secondary school grades, it has been found that there is no significant difference at $p<.050$ significance level. 
Table 6. Results of one way analysis of variance (Anova) conducted to determine whether scores of sub-dimensions of emotional intelligence scale differentiate according to variable of duty term of teachers in the profession or not

\begin{tabular}{|c|c|c|c|c|c|c|}
\hline $\begin{array}{c}\text { Emotional Intelligence Scale } \\
\text { Sub-Dimensions }\end{array}$ & Duty term in the profession & $\mathrm{N}$ & $\mathrm{X}$ & Ss & $\mathrm{F}$ & $\mathrm{P}$ \\
\hline \multirow{4}{*}{ Optimism Mood Regulation } & $1-5$ years & 81 & 48.2099 & 5.51751 & \multirow{4}{*}{.658} & \multirow{4}{*}{.520} \\
\hline & 6-10 years & 14 & 49.2143 & 5.47973 & & \\
\hline & 11 years and more & 11 & 50.0000 & 4.42719 & & \\
\hline & Total & 106 & 48.5283 & 5.39878 & & \\
\hline \multirow{4}{*}{ Utilizations of Emotions } & $1-5$ years & 81 & 20.1728 & 3.92998 & \multirow{4}{*}{1.920} & \multirow{4}{*}{.152} \\
\hline & $6-10$ years & 14 & 21.5714 & 5.09471 & & \\
\hline & 11 years and more & 11 & 22.3636 & 3.07482 & & \\
\hline & Total & 106 & 20.5849 & 4.05878 & & \\
\hline \multirow{4}{*}{ Appraisal of Emotions } & $1-5$ years & 81 & 37.7654 & 6.80307 & \multirow{4}{*}{.177} & \multirow{4}{*}{.701} \\
\hline & $6-10$ years & 14 & 38.7857 & 8.92859 & & \\
\hline & 11 years and more & 11 & 39.4545 & 6.50175 & & \\
\hline & Total & 106 & 38.0755 & 7.03555 & & \\
\hline
\end{tabular}

After one way analysis of variance (ANOVA) test conducted to compare levels of sub-dimensions of emotional intelligence scale of teachers with different duty terms in the profession, it has been found that there is no significant difference at $\mathrm{p}<.050$ significance level.

Table 7. Results of independent group $t$ test conducted to determine whether scores of sub-dimensions of emotional intelligence scale differentiate according to educational level variable of teachers or not

\begin{tabular}{|c|c|c|c|c|c|c|}
\hline $\begin{array}{c}\text { Emotional Intelligence Scale } \\
\text { Sub-Dimensions }\end{array}$ & $\begin{array}{l}\text { Educational } \\
\text { Level }\end{array}$ & $\mathrm{N}$ & $\mathrm{X}$ & Ss & $\mathrm{t}$ & $\mathrm{P}$ \\
\hline \multirow{2}{*}{ Optimism Mood Regulation } & Bachelor's degree & 96 & 48.5313 & 5.45595 & \multirow{2}{*}{.017} & \multirow{2}{*}{.986} \\
\hline & Master's Degree & 10 & 48.5000 & 5.08265 & & \\
\hline \multirow{2}{*}{ Utilizations of Emotions } & Bachelor's degree & 96 & 20.5521 & 3.98912 & \multirow{2}{*}{-.257} & \multirow{2}{*}{.798} \\
\hline & Master's Degree & 10 & 20.9000 & 4.90918 & & \\
\hline \multirow{2}{*}{ Appraisal of Emotions } & Bachelor's degree & 96 & 38.1146 & 7.01257 & \multirow{2}{*}{-.343} & \multirow{2}{*}{.860} \\
\hline & Master's Degree & 10 & 37.7000 & 7.63108 & & \\
\hline
\end{tabular}

After $t$ test conducted to compare levels of sub-dimensions of emotional intelligence scale of teachers with bachelor's degree and master's degree, it has been found that there is no significant difference at $\mathrm{p}<.050$ significance level.

Table 8. Results of independent group $t$ test conducted to determine whether scores of sub-dimensions of emotional intelligence scale differentiate according to marital status variable of teachers or not

\begin{tabular}{|c|c|c|c|c|c|c|}
\hline $\begin{array}{l}\text { Emotional Intelligence Scale } \\
\text { Sub-Dimensions }\end{array}$ & Marital status & $\mathrm{N}$ & $\mathrm{X}$ & Ss & $\mathrm{t}$ & $\mathrm{P}$ \\
\hline \multirow{2}{*}{ Optimism Mood Regulation } & Married & 44 & 47.9318 & 5.77242 & \multirow{2}{*}{-1.176} & \multirow{2}{*}{.242} \\
\hline & Single & 60 & 49.1833 & 5.04049 & & \\
\hline \multirow{2}{*}{ Utilizations of Emotions } & Married & 44 & 20.6364 & 4.44130 & \multirow{2}{*}{.004} & \multirow{2}{*}{.997} \\
\hline & Single & 60 & 20.6333 & 3.83546 & & \\
\hline \multirow{2}{*}{ Appraisal of Emotions } & Married & 44 & 36.9091 & 6.68848 & \multirow{2}{*}{-1.732} & \multirow{2}{*}{.086} \\
\hline & Single & 60 & 39.2667 & 6.98149 & & \\
\hline
\end{tabular}

After $t$ test conducted to compare levels of sub-dimensions of emotional intelligence scale of married and single teachers, it has been found that there is no significant difference at $\mathrm{p}<.050$ significance level. 
Table 9. Results of independent group $t$ test conducted to determine whether scores of sub-dimensions of emotional intelligence scale differentiate according to administrative function status variable of teachers or not

\begin{tabular}{|c|c|c|c|c|c|c|}
\hline $\begin{array}{l}\text { Emotional Intelligence Scale } \\
\text { Sub-Dimensions }\end{array}$ & $\begin{array}{l}\text { Administrative } \\
\text { Function Status }\end{array}$ & $\mathrm{N}$ & $\mathrm{X}$ & Ss & $\mathrm{t}$ & $\mathrm{P}$ \\
\hline \multirow{2}{*}{ Optimism Mood Regulation } & Yes & 9 & 46.7778 & 4.11636 & \multirow{2}{*}{-1.017} & \multirow{2}{*}{.312} \\
\hline & No & 97 & 48.6907 & 5.49121 & & \\
\hline \multirow{2}{*}{ Utilizations of Emotions } & Yes & 9 & 18.2222 & 2.04803 & \multirow{2}{*}{-3.222} & \multirow{2}{*}{.006} \\
\hline & No & 97 & 20.8041 & 4.13481 & & \\
\hline \multirow{2}{*}{ Appraisal of Emotions } & Yes & 9 & 36.6667 & 6.36396 & \multirow{2}{*}{-.626} & \multirow{2}{*}{.533} \\
\hline & No & 97 & 38.2062 & 7.11064 & & \\
\hline
\end{tabular}

After t test conducted to compare levels of sub-dimensions of emotional intelligence scale of teachers with and without administrative function, it has been found that there is significant difference at $\mathrm{p}<.050$ significance level in utilization of emotions sub-dimension in favor of physical education and sports teachers without administrative function.

Table 10. Results of independent group $t$ test conducted to determine whether scores of sub-dimensions of emotional intelligence scale differentiate according to status of doing sports variable of teachers or not

\begin{tabular}{|c|c|c|c|c|c|c|}
\hline $\begin{array}{c}\text { Emotional Intelligence Scale } \\
\text { Sub-Dimensions }\end{array}$ & $\begin{array}{c}\text { Status of Doing } \\
\text { Sports }\end{array}$ & $\mathrm{N}$ & $\mathrm{X}$ & Ss & $\mathrm{t}$ & $\mathrm{P}$ \\
\hline \multirow{2}{*}{ Optimism Mood Regulation } & Yes & 93 & 48.7204 & 5.41007 & \multirow{2}{*}{.980} & \multirow{2}{*}{.329} \\
\hline & No & 13 & 47.1538 & 5.32050 & & \\
\hline \multirow{2}{*}{ Utilizations of Emotions } & Yes & 93 & 20.7849 & 4.10421 & \multirow{2}{*}{1.363} & \multirow{2}{*}{.176} \\
\hline & No & 13 & 19.1538 & 3.53191 & & \\
\hline \multirow{2}{*}{ Appraisal of Emotions } & Yes & 93 & 38.1505 & 7.32914 & \multirow{2}{*}{.293} & \multirow{2}{*}{.770} \\
\hline & No & 13 & 37.5385 & 4.57558 & & \\
\hline
\end{tabular}

After $\mathrm{t}$ test conducted to compare levels of sub-dimensions of emotional intelligence scale of teachers who do sports and who don't do sports, it has been found that there is no significant difference at $\mathrm{p}<.050$ significance level.

Table 11. Results of independent group $t$ test conducted to determine whether scores of sub-dimensions of emotional intelligence scale differentiate according to smoking variable of teachers or not

\begin{tabular}{|c|c|c|c|c|c|c|}
\hline $\begin{array}{c}\text { Emotional Intelligence Scale } \\
\text { Sub-Dimensions }\end{array}$ & $\begin{array}{l}\text { Do You } \\
\text { Smoke? }\end{array}$ & $\mathrm{N}$ & $\mathrm{X}$ & Ss & $\mathrm{t}$ & $\mathrm{P}$ \\
\hline \multirow{2}{*}{ Optimism Mood Regulation } & Yes & 37 & 47.9730 & 5.58513 & \multirow{2}{*}{-.774} & \multirow{2}{*}{.441} \\
\hline & No & 69 & 48.8261 & 5.31357 & & \\
\hline \multirow{2}{*}{ Utilizations of Emotions } & Yes & 37 & 20.4054 & 4.00319 & \multirow{2}{*}{-.332} & \multirow{2}{*}{.741} \\
\hline & No & 69 & 20.6812 & 4.11415 & & \\
\hline \multirow{2}{*}{ Appraisal of Emotions } & Yes & 37 & 37.8919 & 7.54904 & \multirow{2}{*}{-.196} & \multirow{2}{*}{.845} \\
\hline & No & 69 & 38.1739 & 6.79956 & & \\
\hline
\end{tabular}

After t test conducted to compare levels of sub-dimensions of emotional intelligence scale of teachers who smoke and who don't smoke, it has been found that there is no significant difference at $\mathrm{p}<.050$ significance level.

\section{Conclusion and Discussion}

After $\mathrm{t}$ test conducted to compare levels of sub-dimensions of emotional intelligence scale of male and female teachers, it has been found that there is no significant difference at $p<.050$ significance level. In line with this result, it can be concluded that male and female physical education teachers working in Ağrı have similar perceptions related to emotional intelligence.

In the study on physical education teachers, Karamehmetoğlu (2017) found that there was no significant difference between emotional intelligence levels of female physical education teachers and male physical education teachers. In the study on teachers working in primary schools, Ergin (2008) found that emotional intelligence scores did not 
differentiate significantly according to gender. Results obtained from those studies are similar to results of this study. This may be due to the fact that physical education teachers have gone through the same stages in university and sports life and they are in a position to control their emotions thanks to sports.

After one way analysis of variance (ANOVA) test conducted to compare levels of sub-dimensions of emotional intelligence scale of teachers in different ages, it has been found that there is no significant difference at $\mathrm{p}<.050$ significance level. In line with this result, it can be concluded that physical education and sports teachers in different ages and working in Ağrı have similar perceptions related to emotional intelligence.

In the study on administrative officers working in provincial directorates of youth services and sports in Turkey, Beltekin (2015) did not find significant difference between groups according to age variable in emotional appraisal, positive emotional management and positive utilization of emotions sub-dimensions of emotional intelligence levels. In the study on physical education teachers, Adiloğulları (2013) found that emotional intelligence levels and sub-dimensions did not differentiate significantly according to age variable $(\mathrm{p}>0.05)$. Results of those studies are similar to results of this study.

On the other hand, in the study on teachers working in primary schools, Ergin (2008) stated that emotional intelligence levels of teachers in the age group 21-30 was higher than those in the age group 31-40.

After $t$ test conducted to compare levels of sub-dimensions of emotional intelligence scale of teachers working in primary and secondary school grades, it has been found that there is no significant difference at $\mathrm{p}<.050$ significance level. In line with this result, it can be concluded that physical education and sports teachers working in Ağrı have similar perceptions related to emotional intelligence according to education grade.

In the study on different branch teachers, Deniz (2017) found that there was no statistically significant difference between mean scores of emotional intelligence of teachers working in different education grades. This study supports results of the research.

After one way analysis of variance (ANOVA) test conducted to compare levels of sub-dimensions of emotional intelligence scale of teachers with different duty terms in the profession, it has been found that there is no significant difference at $\mathrm{p}<.050$ significance level. In line with this result, it can be concluded that physical education and sports teachers working in Ağrı have similar perceptions related to emotional intelligence according to duty terms in the profession.

In the study on physical education teachers, Karamehmetoğlu (2017) did not find significant difference between emotional intelligence levels of physical education teachers whose professional seniority was less than 5 years and physical education teachers whose professional seniority was more than 5 years. In the study on physical education teachers, Adiloğulları (2013) found physical education teachers' emotional intelligence levels and sub-dimensions did not differentiate significantly according to variable of duty terms in the profession. These studies found similar results supporting the results of the research.

After $t$ test conducted to compare levels of sub-dimensions of emotional intelligence scale of teachers with bachelor's degree and master's degree, it has been found that there is no significant difference at $\mathrm{p}<.050$ significance level. In line with this result, it can be concluded that physical education and sports teachers with different educational level and working in Ağrı have similar perceptions related to emotional intelligence.

In the study on administrative officers working in provincial directorates of youth services and sports in Turkey, Beltekin (2015) did not find significant difference between groups according to educational level variable in emotional appraisal, empathic sensitivity, positive emotional management and positive utilization of emotions sub-dimensions of emotional intelligence levels. This study supports results of the research.

On the other hand, in the study on teachers working in primary schools, Ergin (2008) found that teachers' emotional intelligence scores differentiated significantly according to the last school which they graduated from. When their ranking averages are taken into consideration, it is seen that they are ranked as postgraduate, teacher high school, 2-year institute, college, 3-year educational institute and 4-year faculty.

After $t$ test conducted to compare levels of sub-dimensions of emotional intelligence scale of married and single teachers, it has been found that there is no significant difference at $\mathrm{p}<.050$ significance level. In line with this result, it can be concluded that physical education and sports teachers with different marital status and working in Ağrı have similar perceptions related to emotional intelligence.

Adiloğulları (2013) found that physical education teachers' emotional intelligence levels and sub-dimensions did not differentiate significantly according to marital status variable. This study supports results of the research.

On the other hand, in the study on women, Dal (2015) found that married individuals had higher emotional 
intelligence scores than single/widow individuals.

After $t$ test conducted to compare levels of sub-dimensions of emotional intelligence scale of teachers with and without administrative function, it has been found that there is significant difference at $\mathrm{p}<.050$ significance level in utilization of emotions sub-dimension in favor of physical education and sports teachers without administrative function. In line with this result, it can be concluded that physical education and sports teachers working in Ağrı do not have similar perceptions related to emotional intelligence according to administrative function.

On the other hand, in the study on employees working in provincial directorates of youth services and sports, Öner (2018) found that there was no significant difference between the total score of emotional intelligence levels of employees in management group, administrative services group and employees working in other services.

After $t$ test conducted to compare levels of sub-dimensions of emotional intelligence scale of teachers who do sports and who don't do sports, it has been found that there is no significant difference at $p<.050$ significance level. In line with this result, it can be concluded that physical education and sports teachers working in Ağrı and doing sports and not doing sports have similar perceptions related to emotional intelligence.

On the other hand, in the study on athletes engaged in individual and team sports and people not doing sports, Özdenk (2015) found that scores of sedentary group were high in determination, happiness, impulse control, realism, self-esteem, problem solving, social responsibility, interpersonal relations, empathy, independence, self-development sub-dimensions which were emotional intelligence sub-dimensions when emotional intelligence scale scores of team sports, individual athletes and sedentary groups were examined and difference between them was statistically significant.

After $t$ test conducted to compare levels of sub-dimensions of emotional intelligence scale of teachers who smoke and who don't smoke, it has been found that there is no significant difference at $\mathrm{p}<.050$ significance level. In line with this result, it can be concluded that physical education and sports teachers working in Ağrı have similar perceptions related to emotional intelligence according to smoking variable.

\section{References}

Adiloğulları, G. E. (2013). Investigation of the Relationship Between Emotional Intelligence and Professional Burnout Levels of Physical Education Teachers (Master thesis, Sütçü İmam University).

Austin, E. J., Saklofske, D. H., Huang, S. H., \& McKenney, D. (1998). Measurement of trait emotional intelligence: Testing and cross-validating a modified version of Schutte et al.'s (1998) measure. Personality and individual differences, 36(3), 555-562.

Başaran, I. (2004). Effective learning and multiple intelligence theory: A review. Ege Eğitim Dergisi, 7-15.

Başaran, İ. E. (1996). Turkey Education System. Ankara: Yargıcı Publication.

Belenli, T. (2014). History Teaching and Multiple Intelligence Theory: How to Teach History. Istanbul: New Human.

Beltekin, E. (2015). Turkey's Youth Services and Sports Provincial Directorate of Personnel Emotional Intelligence and Investigation Serve Manager of Organizational Commitment Level (Master thesis, University of Erciyes).

Çakar, U., \& Arbak, Y. (2004). Changing emotion-intelligence relationship and emotional intelligence in the light of modern approaches. Dokuz Eylül University Social Sciences Institute adolescent, 3, 23-27.

Çoban, B., \& Ünveren, A. (2007). Physical education and game teaching. Ankara: Nobel Publishing.

Cooper, R. K., \& Sawaf, A. (1997). Executive EQ: Emotional Intelligence in Leadership and Organisations. Grosset/Putnum, New York.

Dal, E. (2015). Examining the Relationship between Emotional Intelligence Level and Life Satisfaction in Women (Master thesis, Üsküdar University).

Demirci, S. F. (2011). Education and Productivity. Education in the Light of Science and Intelligence, 141, 14-21. https://doi.org/10.1007/BF03341610

Deniz, C.. (2017). A Study on the Investigation of the Relationship Between Emotional Intelligence Feature and Vocational Self-Esteem of Different Branch Teachers (Master thesis, Arel University).

Doğan, S., \& Şahin, F. (2007). Emotional intelligence: A historical view of its historical development and importance to organizations. Çanakkale University Institute of Social Sciences adolescent, 1, 231-252.

Ergin, D. (2008). Teacher Perceptions of Emotional Intelligence and Transformational Leadership in School 
Management (Master thesis, Kocaeli University).

Eroğlu, O. (2006). Research methods in education. Monitoring Research. Ankara University Institute of Educational Sciences Educational Administration, Inspection, Planning and Economics Master's Program without Thesis, Ankara.

Fidan, N. (2012). Learning and Teaching at School (3rd ed.). Pegem Academy Publishing, Ankara.

Göçet, E. (2006). Relationship Between Emotional Intelligence Levels of University Students and Their Attitudes to Coping with Stress (Master thesis, Department of Educational Sciences, Institute of Social Sciences, Sakarya University).

Goleman, D. P. (2014). Why Emotional Intelligence Matters More Than IQ? B. Seçkin Yüksel (Translated), Istanbul: Varlık Publishing.

Karamehmetoğlu, M. (2017). Investigation of the Role of Emotional Intelligence Levels of Physical Education Teachers in Determining Professional Self-Efficacy and Problem Solving Skills (Master thesis, Marmara University).

Küçük, Z. A. (2012). Primary school administrators' views on education and its aims (Master thesis, Institute of Social Sciences, Kastamonu University).

Laminack, L. L., \& Long, B. M. (1985). What Makes a Teacher Effective-Insight from Preservice Teachers. The Clearing House, 58(6), 268-269. https://doi.org/10.1080/00098655.1985.9955558

Nebioğlu, D. (2004). General Principles of Physical Education Lesson Planning and Control. Ankara: Nobel Publishing.

Öner, N. (2018). Investigation of the Learned Strength and Emotional Intelligence Levels of the Provincial Directorate of Youth Services and Sports (M.Sc. thesis, Akdeniz University).

Özdenk, S. (2015). Investigation of Emotional Intelligence and Leadership Characteristics of Individual and Team Sports Athletes and Non-Sports Individuals ( $\mathrm{PhD}$ thesis, Gazi University).

Özmen Ö. (1999). Education Triangle in Contemporary Sports (2nd ed.). Ankara, Bağırgan Publishing House.

Salovey, P., \& Mayer, J. D. (1990). Emotional intelligence. Imagination, cognition and personality, 9(3), 185-211. https://doi.org/10.2190/DUGG-P24E-52WK-6CDG

Schutte, N. S., Malouff, J. M., Hall, L. E., Haggerty, D. J., Cooper, J. T., Golden, C. J., \& Dornheim, L. (1998). Development and validation of a measure of emotional intelligence. Personality and Individual Differences, $25,167-177$.

Selçuk, Z., Kayıl1, H., \& Okut, L. (2004). Multiple Intelligence Applications. Ankara.

Şişman, M. (1999). Introduction to Teaching. Ankara: Pegem.

Tatar, A., Tok, S., \& Saltukoglu, G. (2011). Adaptation of the revised Schutte emotional intelligence scale into Turkish and examination of its psychometric properties. Bulletin of Clinical Psychopharmacology, 21(4), 325-338. https://doi.org/10.5455/bcp.20110624015920

Tuğrul, C. (1999). Emotional Intelligence. Clinical Psychiatry, 1, 12-20.

Tunç, H. (1999). Introduction to Physical Education and Sports Science Lecture Notes. Niğde.

Yavaş. M., \& İlhan, A. (1997). Special Teaching Methods in Physical Education and Sports (2nd ed.). Bursa.

Yetim, A. (2005). Sociology and sports. Istanbul: Morpa Culture Publications.

Yörükoğlu, A. (2004). Children’s mental health (pp. 105-106). Istanbul: Özgür Publishing.

\section{Copyrights}

Copyright for this article is retained by the author(s), with first publication rights granted to the journal.

This is an open-access article distributed under the terms and conditions of the Creative Commons Attribution license (http://creativecommons.org/licenses/by/4.0/). 